\title{
Kinerja Reproduksi Sapi Brahman Cross di Kabupaten Batubara
}

\section{Reproductive Performances of Brahman Cross Cattle in Batubara Regency}

\author{
Solehudin dan Muhammad Syawal Hasibuan) \\ ${ }^{1)}$ Loka Penelitian Kambing Potong \\ PO Box 1 Galang Kab. Deli Serdang - Sumatera Utara \\ solehudintahero2@gmail.com
}

\begin{abstract}
Diterima : : o1 Desember 2019
Disetujui : 24 Februari 2020

Diterbitkan : 29 Februari 2020
\end{abstract}

\begin{abstract}
Abstrak: Kabupaten Batubara merupakan salah satu daerah di Sumatera Utara yang mendapat sasaran program pengembangan bibit sapi unggul yaitu Brahman cross. Penelitian ini bertujuan untuk mengevaluasi kinerja reproduksi sapi Brahman cross di Kabupaten Batubara. Metode yang digunakan adalah survey dengan pengambilan sampel secara purposive sampling. Materi penelitian adalah 100 ekor sapi induk Brahman cross yang diambil masing-masing 25 ekor dari 4 kelompok tani di 3 kecamatan yaitu Kelompok Sentosa (Kecamatan Sei Balai), Kelompok Anugerah (Kecamatan Sei Suka), Kelompok Karya Mandiri dan Tunas Muda (Kecamatan Limapuluh). Parameter yang diukur adalah umur pertama kawin, service per conception (s/c), post partum mating (ppm) dan calving interval (ci). Data dialisis secara deskriptif. Hasil penelitian menunjukkan bahwa rataan umur pertama kawin adalah 36 bulan, nilai s/c adalah 3,15, post partum mating adalah 9 bulan dan lama calving interval adalah 18 bulan. Dapat disimpulkan bahwa kinerja reproduksi sapi Brahman cross di Kabupaten Batubara masih jelek. Penyebabnya adalah manajemen pemberian pakan yang buruk dan sistem perkawinan yang belum tepat. Walaupun demikian, kelompok Anugerah dapat dijadikan model pengembangan bibit sapi Brahman cross di Kabupaten Batubara karena sudah mengembangkan manajemen pemeliharaan dengan baik.
\end{abstract}

Kata Kunci: calving interval, post partum mating reproduksi, service per conception

\begin{abstract}
Batubara Regency is one of the regions in North Sumatera that has been targeted by the program of superior cattle breeding. This study was aimed to evaluate the reproductive performance of Brahman cross cow in Batubara Regency. The method used survey by taking a purposive sampling. A total of 100 head Brahman cross cows taken each of 25 head from 4 farmer groups in 3 districts namely Sentosa Group (Sei Balai District), Anugerah Group (Sei Suka District), Karya Mandiri Group and Tunas Muda (Limapuluh District). The parameters measured were age of first mating, service per conception (s/c), post partum mating (ppm) and calving interval (ci). Data were analyzed descriptively. The results showed that the average age of first mating was 36 months, the value of s / $c$ was 3.15, post partum mating was 9 months and the length of calving interval was 18 months. It can be concluded that the reproductive performance of Brahman cross cow in Batubara Regency is still poor. The reason were poor of feeding management and improper of mating system. Nevertheless, the Anugerah group can be used as a model for developing Brahman cross cattle in Batubara Regency because it has developed good maintenance management.
\end{abstract}

Keywords: calving interval, post partum mating reproduction, service per conception.

\section{Pendahuluan}

Dalam rangka mendukung program swasembada daging Indonesia tahun 2026, Kementerian Pertanian melalui Direktorat Jenderal Peternakan dan Kesehatan Hewan menggalakkan program pembibitan sapi unggul yang bekerjasama dengan Dinas Ketahanan Pangan Provinsi Sumatera Utara. Salah satu daerah yang mendapat sasaran program ini adalah Kabupaten Batubara dengan alasan karena kabupaten ini memiliki potensi besar untuk pengembangan sapi unggul dengan sumber daya alam yang mendukung. Program ini mulai berjalan tahun 2017 dengan sapi unggul yang digunakan adalah sapi Brahman Cross (BX) yang diimpor dari Australia. Sapi tersebut diimpor dengan maksud dikembangbiakan menjadi indukan yang dapat menghasilkan keturunan untuk dijadikan sapi potong.

Sapi Brahman Cross (BX) merupakan sapi persilangan antara sapi Brahman keturunan Bos indicus dan sapi Eropa keturunan Bos taurus. Sapi BX sangat cocok untuk penggemukan dan memiliki 
kinerja yang lebih baik daripada sapi lokal [1]. Selain itu, sapi BX juga tahan terhadap cuaca ektrim dan penyakit sehingga dapat tumbuh dengan baik di musim kemarau tanpa menimbulkan menurunnya nafsu makan [2]. Pertambahan bobot badan hidup (pbbh) sapi Brahman cross berkisar antara 1,0-1,8 $\mathrm{kg} / \mathrm{ekor} /$ hari bahkan dalam kondisi yang sangat mendukung dapat mencapai $2 \mathrm{~kg} /$ ekor/hari [3]. Jika dibandingkan sapi lokal, persentase karkas pun lebih tinggi dengan komponen tulang yang lebih rendah daripada daging sehingga sangat diminati oleh feedloter [4]. Bobot karkas sapi Brahman cross dapat mencapai $54,40 \%$ dan bobot dagingnya dapat mencapai 73,29\% [5].

Penelitian bertujuan untuk mengevaluasi kinerja reproduksi sapi betina Brahman cross sebagai indukan di Kabupaten Batubara. Hasil penelitian bermanfaat sebagai informasi dalam menunjang kesuksesan program perbanyakan populasi sapi potong.

\section{Materi dan Metode}

Penelitian dilaksanakan pada bulan November 2019 dengan lokasi penelitian pada empat kelompok tani di tiga kecamatan yaitu Kelompok Sentosa di Kecamatan Sei Balai, Kelompok Anugerah di Kecamatan Sei Suka, Kelompok Karya Mandiri dan Kelompok Tunas Muda di Kecamatan Limapuluh. Materi yang digunakan dalam penelitian adalah 100 ekor sapi induk Brahman cross umur rata-rata 3 tahun yang diambil dari masing-masing kelompok tani sebanyak 25 ekor. Sampel dipilih secara acak dari seluruh ternak yang ada di kelopok tani tersebut. Metode penelitian adalah survey dengan pengambilan data primer dari peternak secara langsung.

Parameter yang diamati adalah umur pertama kawin, service/conception (s/c), post partum mating (ppm) dan calving interval (ci). Umur pertama kawin merupakan umur ketika ternak dikawinkan untuk pertama kali. Service/conception (s/c) merupakan perbandingan antara banyaknya perlakuan inseminasi buatan tiap ekor dengan jumlah ternak sampai terjadi kebuntingan [6]. Post partum mating (ppm) merupakan waktu yang dibutuhkan induk untuk dikawinkan lagi setelah beranak [7]. Calving interval (ci) merupakan jarak waktu antara dua kelahiran yang berurutan [8].

Analisis data menggunakan metode deskriptif dengan cara mentabulasi seluruh data yang diperoleh kemudian dirata-ratakan. Hasil akhir data yang diperoleh kemudian dibandingkan dengan literatur dan hasil penelitian yang telah dilakukan.

\section{Hasil dan Pembahasan}

Kinerja reproduksi sapi Brahman croos (BX) yang meliputi umur pertama kawin, service/conception (s/c), post partum mating (ppm) dan calving interval (ci) di Kabupaten Batubara disajikan pada Tabel 1.

Tabel 1. Kinerja reproduksi sapi Brahman cross di Kabupaten Batubara

\begin{tabular}{|c|c|c|c|c|c|}
\hline \multirow[b]{2}{*}{ Parameter Reproduksi } & \multicolumn{4}{|c|}{ Rataan Tiap Kelompok } & \multirow[b]{2}{*}{$\begin{array}{c}\text { Rataan } \\
\text { Keseluruhan }\end{array}$} \\
\hline & Sentosa & Anugerah & $\begin{array}{c}\text { Karya } \\
\text { Mandiri }\end{array}$ & $\begin{array}{l}\text { Tunas } \\
\text { Muda }\end{array}$ & \\
\hline Umur pertama kawin (bulan) & 48 & 24 & 36 & 36 & 36 \\
\hline Service/conception (kali) & 3,0 & 1,6 & 4,0 & 4,0 & 3,15 \\
\hline Post partum mating (bulan) & 15 & 3 & 9 & 9 & 9 \\
\hline
\end{tabular}

Rataan umur pertama kawin sapi Brahman cross (BX) di Kabupaten Batubara yaitu pada umur 36 bulan (3 tahun). Kelompok Anugerah memiliki rataan umur pertama kawin paling cepat dibandingkan kelompok lainnya. Sedangkan kelompok Sentosa memiliki rataan umur pertama kawin paling lambat. Rataan umur pertama kawin keseluruhan ternak pada penelitian ini lebih besar dari kondisi ideal menurut [9] yang menyatakan bahwa umur pertama kawin untuk sapi adalah 18-24 bulan. Selain kelompok Anugerah, rataan ketiga kelompok melebihi waktu ideal untuk dikawinkan. Jika sapi dara telah melebihi waktu ideal untuk dikawinkan, maka akan berpengaruh terhadap penampilan reproduksinya [10]. Perkawinan pertama yang terlambat sampai 3 tahun cenderung menurunkan kinerja reproduksi [11].
Penyebab umur pertama kawin yang terlambat pada penelitian ini dimungkinkan karena ternak mengalami dewasa kelamin yang terlambat sehingga berpengaruh terhadap umur pertama estrus. Terlambatnya dewasa kelamin dimungkinkan karena kurangnya asupan nutrisi yang baik kepada ternak. Hal ini bisa dilihat dari manajemen pemberian pakan pada keempat kelompok ternak tersebut. Pada kelompok Anugerah, hijauan disediakan secara adlibitum sehingga ternak mendapatkan pakan yang cukup sehingga umur pertama kawin dapat dilakukan pada umur 24 bulan ( 2 tahun). Berbeda dengan ketiga kelompok lainnya yang memberikan hijauan kepada ternak dengan jumlah yang tidak mencukupi kebutuhan ternak. Pengaruh kualitas nutrisi juga dapat dilihat Skor Kondisi Tubuh (SKT) pada masingmasing kelompok. Nilai SKT pada kelompok 
Anugerah mempunyai rataan 4 (skala 1-5) yang merupakan rataan nilai SKT terbaik dibandingkan dengan kelompok Sentosa (rataan 2), kelompok Karya Mandiri (rataan 3) dan kelompok Tunas Muda (rataan 3). Kekurangan nutrisi pada tubuh menyebabkan umur pubertas ternak terlambat yang selanjutnya berpengaruh juga pada umur dewasa kelamin. Ternak sebaiknya dikawinkan setelah dewasa kelamin karena pada saat pubertas asupan nutrisi akan digunakan oleh ternak untuk pertumbuhan tubuhnya [12].

Rataan nilai service/conception (s/c) adalah 3,15 dengan rataan kelompok terbaik yaitu kelompok Anugerah dengan nilai s/c 1,6. Kelompok Karya Mandiri dan Tunas Muda memiliki nilai s/c paling buruk yaitu masing-masing 4,o. Rataan angka s/c pada penelitian ini merupakan rataan nilai s/c paling jelek di antara penelitian yang lain terhadap dengan jenis sapi yang berbeda. Hasil penelitian [13] menyatakan bahwa nilai s/c pada sapi Bali di Kabupaten Pringsewu Provinsi Lampung adalah 1,76. Sedangkan hasil penelitian [14] menyatakan bahwa nilai s/c sapi Peranakan Ongole (PO) di BPPIBT-SP Ciamis adalah 2,11, yang hampir sama dengan hasil penelitian [10] yang menyatakan bahwa nilai s/c sapi peranakan Simmental di Kabupaten Tulungagung Jawa Timur dengan nilai 2,09. Nilai s/c pada kelompok Anugerah paling baik dibandingkan kelompok lainnya dimungkinkan karena perbedaan manajemen perkawinan.

Sistem perkawinan sapi dara pada kelompok Anugerah menggunakan kawin alam sedangkan perkawinan dengan menggunakan teknik IB dilakukan setelah ternak partus pertama. Berbeda dengan kelompok lainnya dimana perkawinan sapi dara langsung menggunakan teknik IB. Hal ini sesuai dengan pendapat [15], yang menyatakan bahwa fertilitas sapi dara lebih rendah daripada sapi yang telah beranak, sehingga fertilitas ternak di kelompok Anugerah lebih baik daripada kelompok lainnya. Tingginya nilai s/c berpengaruh terhadap nilai ekonomi karena semakin besar nilai s/c, maka pengeluaran untuk melakukan IB semakin besar. Nilai s/c sebenarnya dapat diperbaiki salah satunya dengan perbaikan mutu pakan [16]. Tetapi hal itu tidak dilakukan oleh kelompok ternak tersebut sehingga mengakibatkan kawin berulang pada ternak yang akhirnya nilai s/c semakin tinggi.

Rataan umur post partum mating pada penelitian ini adalah 9 bulan. Kelompok Anugerah merupakan kelompok yang paling cepat dalam mengawinkan ternak setelah beranak yaitu 3 bulan. Sedangkan kelompok Sentosa merupakan kelompok yang paling lama mengawinkan ternaknya setelah beranak yaitu 15 bulan. Rataan umur post partum mating pada penelitian ini lebih panjang daripada penelitian [17] terhadap sapi potong di Kecamatan Mojogedang Kabupaten Karanganyar yaitu sapi
Simmental - PO dan PO masing-masing 3,85 bulan dan 4,42 bulan. Sapi sebaiknya dikawinkan kembali setelah 3 bulan dari melahirkan sehingga dapat beranak sekali dalam 1 tahun. Sapi yang tidak birahi dalam 4 bulan dikatakan sebagai sapi lambat birahi [18].

Salah satu penyebab post partum mating yang lambat pada penelitian ini dimungkinkan karena kualitas pakan yang rendah. Hal ini karena kualitas pakan berpengaruh terhadap hormon reproduksi. Kualitas pakan yang rendah menyebabkan lambatnya aktivitas hormon gonadotrophin releasing hormone (GnRH) sehingga folicle stimulating hormone (FSH) dan luteunizing hormone ( $\mathrm{LH}$ ) dari hypofisis menjadi terlambat yang berakibat pada lambatnya post partum mating [19]. Akibat lambatnya post partum mating dapat dilihat dari jumlah populasi sapi antara induk dan anak. Populasi sapi pada kelompok Anugerah sudah mencapai 74 ekor dalam 2 tahun. Sedangkan kelompok yang lain-lain masih kurang dari 50 ekor.

Rataan calving interval pada penelitian ini adalah 18 bulan. Kelompok Anugerah merupakan kelompok yang memiliki calving interval paling pendek dibandingkan kelompok lainnya yaitu 12 bulan. Sedangkan calving interval paling panjang diperoleh pada kelompok Sentosa yaitu 24 bulan (2 tahun). Rataan calving interval pada penelitian ini lebih panjang daripada sapi peranakan Simmental di Kabupaten Tulungagung Jawa Timur yang mencapai 15,07 bulan [10]. Lama calving interval lebih dari 420 hari termasuk kategori sangat jelek [20]. Faktor yang mempengaruhi calving interval adalah post partum mating dan nilai s/c [21]. Semakin panjang post partum mating maka semakin panjang pula calving interval ternak tersebut. Demikian juga dengan s/c, semakin tinggi nilai s/c maka semakin panjang pula calving interval. Di samping itu, panjangnya calving interval dalam penelitian ini dimungkinkan karena lamanya penyapihan pedet. Induk yang menyusui akan mensekresikan hormon prolaktin dalam kadar yang tinggi yang menyebabkan hipotalamus dan hipofisis memberikan umpan negatif sehingga hormon gonadotrophin yang mempengaruhi estrus dan ovulasi kinerjanya menurun [22].

\section{Kesimpulan}

Berdasarkan hasil penelitian di atas dapat disimpulkan bahwa secara keseluruhan rataan kinerja reproduksi sapi Brahman cross di Kabupaten Batubara masih jelek sehingga perlu ditingkatkan terutama manajemen pemberian pakan dan sistem perkawinan. Namun, terdapat satu kelompok tani yang telah berhasil menunjukkan manajemen pemberian pakan dan sistem perkawinan yang baik sehingga dapat dijadikan model untuk perbaikan pengembangan sapi Brahman cross di Kabupaten Batubara yaitu kelompok Anugerah. 


\section{Referensi}

[1] Soeharsono, Saptati RA, Diwyanto K. Kinerja Reproduksi Sapi Potong Lokal dan Sapi Persilangan Hasil Inseminasi Buatan di Daerah Istimewa Yogyakarta. Prosiding Seminar Nasional Peternakan dan Veteriner, Puslitbang Peternakan, 2010.

[2] Socheh M, Saleh MD, Widiawati. Post Partum Heat dan Intensitas Estrus Induk Sapi Brahman Berbasis Penyapihan Umur Pedet yang Berbeda. Prosiding Seminar Teknologi dan Agribisnis Pertanian V, Universitas Jenderal Soedirman, 2017.

[3] Mustofa Z. Analisis Pemasaran Sapi Potong di Kabupaten Blora Jawa Tengah. Prosiding Seminar Fakultas Peternakan IPB, 2001.

[4] Hadi PU, Ilham N. Peluang Pengembangan Usaha Pembibitan Ternak sapi Potong di Indonesia dalam Rangka Swasembada Daging 2005. PSE, Bogor, 2000.

[5] Jazulie MI, Nasich M, Susilawati T, Kuswati. Distribusi Komponen Karkas Sapi Brahman cross (BX) Hasil Penggemukan pada Umur Pemotongan yang Berbeda. J. Ilmu-Ilmu Peternakan, 25 (1):24-34, 2015.

[6] Aidilof. Penampilan Reproduksi Sapi Aceh dengan Sapi Brahman dan dengan Sapi Simmental melalui Inseminasi Buatan di Kecamatan Padang Tiji. Sains Riset, 5 (1):1-10, 2015.

[7] Wahyudi, RP. Penampilan Reproduksi Sapi Induk Peranakan Ongole dan Silangan Simmental dengan Peranakan Ongole di Kecamatan Nguter Kabupaten Sukoharjo. Skripsi S1 Fakultas Peternakan Universitas Sebelas Maret, Surakarta,2014.

[8] Rasad, SD. Evaluasi Penampilan Reproduksi Sapi Perah (Studi Kasus di Perusahaan Peternakan KUD Sinarjaya). Agripet, 9(1):43-49, 2009.

[9] Handiwirawan E, Subandriyo. Potensi dan Keragaman Genetik sapi Bali. Prosiding Seminar Teknologi Peternakan dan Veteriner, Puslitbang Peternakan, 2007.

[10] Desinawati N, Isnaini N. Penampilan Reproduksi Sapi Peranakan Simmental di Kabupaten Tulungagung Jawa Timur. J. Ternak Tropika, 11(2):41-47, 2010.

[11] Hardjopranjoto HS. Ilmu Kemajiran pada Ternak. Surabaya:Airlangga University Press, 1995.

[12] Toelihere MR. Fisiologi Reproduksi Ternak. Bandung:PT Angkasa , 1993.

[13] Suharyati S, Hartono M. Pengaruh Manajemen Peternak terhadap Efisiensi Reproduksi Sapi Bali di Kabupaten Pringsewu Provinsi Lampung. J. Penelitian Pertanian Terapan, 16(1):61-67, 2015.
[14] Putra WPB, Gunawan M, Kaiin EM, Said S. Kinerja Reproduksi Sapi Peranakan Ongole (Bos indicus) di BPPIBT-SP Ciamis, Jawa Barat. Prosiding Seminar Teknologi dan Agribisnis Peternakan VI, Fakultas Peternakan Universitas Jenderal Soedirman, 2018.

[15] Djanuar. Fisiologi Reproduksi dan Inseminasi Buatan pada Sapi. Yogyakarta: Gadjah Mada University, 1985.

[16] Bindari YR, Shrestha S, Gaire TN. Effect of Nutrition on Reproduction. A review. Adv App Sci Res 4 (1):421-429, 2013.

[17] Riyanto J, Lutojo, Barcelona DM. Kinerja Reproduksi Induk Sapi Potong pada Usaha Peternakan Rakyat di Kecamatan Mojogedang. Sains Peternakan, 13 (2): 73-79, 2015.

[18] Sutiyono, Samsudewa D, Suryawijaya A. Identifkasi Gangguan Reproduksi Sapi Betina di Peternakan Rakyat. J. Veteriner, 18(4):580-588, 2017.

[19] Pradhan R, Nakagoshi N. Reproductive Disosders in Cattle due to Nutritional Status. J Inter Dev and Coop 14:45-66, 2008.

[20] Fodor I, Ozsvari L. The Evaluation of Reproductive Performance in Dairy Herds. http://real.mtak.hu/24781/1/ICoM_2015papero85.pdf, 2015 diakses tanggal 30 November 2019.

[21] Winarti E, Supriyadi. Penampilan Reproduksi Ternak sapi Potong Betina di Daerah Istimewa Yogyakarta. Prosiding Seminar Teknologi Peternakan dan Veteriner, Puslitbang Peternakan, 2010.

[22] Hafez ESE. Reproduction in Farm Animal. 7th Edition. Philadelphia: Lea and Febigher, 2004. 